\title{
Assessment of knowledge and attitude regarding organ donation: a community based Study
}

\author{
Devgan S. ${ }^{1}$, Monga S. ${ }^{2 *}$, Gupta S. ${ }^{3}$, Dhingra R. ${ }^{4}$, Chaudhary S. ${ }^{5}$, Singh G. ${ }^{6}$ \\ DOI: https://doi.org/10.17511/ijphr.2015.i4.06 \\ 1 Shalini Devgan, Assistant Professor, Department of Community Medicine, Guru Gobind Singh Medical College and Hospital, Faridkot, \\ Punjab, India. \\ 2* Shamim Monga, Assistant Professor, Department of Community Medicine, Guru Gobind Singh Medical College and Hospital, Faridkot, \\ Punjab, India. \\ ${ }^{3}$ Sanjay Gupta, Professor \& Head, Department of Community Medicine, Guru Gobind Singh Medical College and Hospital, Faridkot, Punjab, \\ India. \\ ${ }^{4}$ Rachna Dhingra, Medical Officer, Civil Hospital, Ferozepur, Punjab, India. \\ 5 Sanjay Chaudhary, Assistant Professor, Department of Community Medicine, Guru Gobind Singh Medical College and Hospital, Faridkot, \\ Punjab, India. \\ 6 Gaganpreet Singh, Assistant Professor, Department of Community Medicine, Guru Gobind Singh Medical College and Hospital, Faridkot, \\ Punjab, India.
}

Background: Organ transplants can save lives. People needing tissue transplants can also be of any age. In some cases, tissues can save lives. Aim of the study: is to assess and determine the corelation between the knowledge and Attitude regarding organ donation among individuals in the community.Material and Methods: A Cross Sectional, Community based descriptive study was conducted on population of Mullana District Ambala. A sample size of 200 was selected by using the simple random technique. A structured questionnaire for knowledge and attitude scale was used to collect data from general population. Results: Out of 200 participants 39\% were between 15-25 age group, $64 \%$ of them were males, $52 \%$ family were joint family, a high percentage $64 \%$ were of Sikh religion and majority $40 \%$ were educated till primary. The family income of $76 \%$ was below the poverty line and major $43 \%$ source of awareness was T.V/Radio. The mean score of knowledge was 5.21 and SD 3.25 and the mean score for attitude was 23.12 and SD 4.12 with positive correlation between the knowledge and Attitude regarding organ donation i.e. $r=0.082$.Conclusion: Efficient knowledge may ultimately translate into the awareness of organ donation. Efficient measures should be taken to educate the population with relevant information.

Keywords: Organ Donation, Living Donation, Deceased Donation

Corresponding Author

Shamim Monga, Assistant Professor, Department of Community Medicine, Guru Gobind Singh Medical College and Hospital, Faridkot, Punjab, India.

Email: shamimmonga@yahoo.com
How to Cite this Article

Devgan S, Monga S, Gupta S, Dhingra R, Chaudhary $\mathrm{S}$, Singh G. Assessment of knowledge and attitude regarding organ donation: a community based Study. Public Health Rev Int J Public Health Res. 2015;2(4):56-60. Available From https://publichealth.medresearch.in/index.php/ijphr/ article/view/20
To Browse

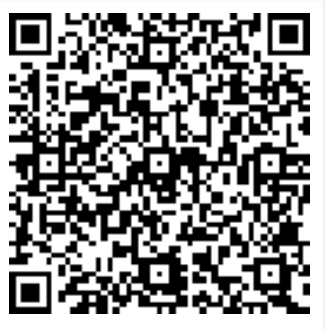

Manuscript Received 2015-11-25

Conflict of Interest No

Review Round 1
2015-12-04
Funding
Nil

(c) 2015 by Shalini Devgan, Sha Comn
Review Round 2 2015-12-17 


\section{Introduction}

People requiring organ transplants are usually very ill or dying because of their own organ is failing. They range from young babies and children through to older people. Some need transplants because they are born with a physical problem or a disease that causes organ failure. Others may have contracted a disease or acquired an injury. Organ transplants can save lives. People needing tissue transplants can also be of any age. In some cases, tissues can save lives [1]. Organ transplantation is the moving of an organ from one body to another or from a donor site to another location on the patient's own body, for the purpose of replacing the recipient's damaged or absent organ [2]. Organs of the body that can be transplanted include: Kidney, Heart, Liver, Lung, Pancreas, Intestines. Tissues that can be donated include: Cornea (coating of the eyeball), Middle ear, Skin, Heart valves, Bone, Veins, Cartilage, Tendons, Ligaments, Stem cells, blood, and blood platelets can also be donated [3]. There are two ways of Organ donation the first is, living related donors only immediate blood relations (brother, sister, parents \& children) can donate as per the Transplantation of Human Organ Act 1994 [4]. Living donor can donate only few organs, one kidney (as one kidney is capable of maintaining the body functions), a portion of the pancreas (as half of the pancreas is adequate for sustaining pancreatic functions) and part of the liver (as the few segments that are donated will regenerate after a period of time) can be donated and second is cadaver Organ donor can donate all organs after brain death [4].

Organ donation is the donation of biological tissue or an organ of the human body from a living or dead person to a living recipient in need of a transplantation [5].

Knowledge refers to the amount of information and understanding about the organ donation in general population as measured by structured questionnaire schedule.

Attitude refers to the opinion or feeling that general population have about organ donation and the way they behave towards organ donation .

Correlation refers to examining the strength and relationships between two variables that is knowledge regarding organ donation and attitude regarding organ donation. Correlations may be either positive or negative [6].
Aim to assess and determine the co- relation between the knowledge and Attitude regarding organ donation among individuals in the community.

\section{Material and Methods}

Cross Sectional, Community based descriptive study was conducted in Field practice area of MMIMSR, Mullana District Ambala. Ethical clearance was taken from ethical committee of the Institute. All male and females who fulfilled selection criteria in households of village Budiyo of field practice area of Department of Community Medicine, MMIMSR, Mullana, Ambala were included in the Study.

The study duration was 6 months in which 100 households of Village Budiyo were selected by simple random sampling. Persons aged above 15 years those who can read and write or understand in any language were included in the study. Written consent to participate in the study was obtained from each subject. After covering whole village total sample of 200 individuals was achieved.

The Research tool consists of structured questionnaire regarding demographic Variables, Knowledge of organ donation and attitude scale statements.

01. Demographic data consisting of student profile such as Age in years, gender, religion, marital status, type of family, educational discipline, family Income, domicile or place of living, and source of awareness of organ donation .

02. The structured questionnaire consists of 10 questions to test the Knowledge. A score of one was given for each correct response and a score 0 was given for each incorrect response. The total knowledge score was 10 .

01. Classification of knowledge score based on arbitrary division

- Below 50 \%- Inadequate knowledge

- $50-80 \%$-Moderate adequate knowledge

- Above $80 \%$-Adequate knowledge

03. Attitude scale consists of 8 items related to organ donation attitude questions were assessed by 5 point Likert's scales ranged from strongly agree to strongly disagree. In the attitude scale equal positive and negative statements selected. For negative statement reverse score was used. 


\section{Classification of attitude scores based on arbitrary division}

- Below $50 \%$-Negative attitude

- 50-80\%-Uncertain attitude

- Above $80 \%$ - Positive attitude

A pilot testing of Performa was conducted on 10 individuals to assess the feasibility of the study by using predesigned Performa. Based on the observation, certain minor modifications were done and the Performa was used for data collection from individuals in the community. The study samples were selected based on selection criteria. The data was collected from all the study subjects and was compiled and analyzed by using appropriate statistical methods. Correlation of knowledge and attitude scores was calculated using Pearson's correlation method.

\section{Results}

The results of present study shows total 200 subjects were participated in the study out of them 128 male and 72 were female. From study population 78 were in 15-25 year of age group, 52 were in 26-35 year ,33 were in 36-45 year, 17 were in 46-55 year, 13 were in 56-65 year and 7 were in $>65$ year of age.(Table 1 ). In all the subjects 56 belonged to Hindu, 2 to Christian, 13 to Muslim and 129 from Sikh religions. 104 subjects were staying in joint family and 96 were staying in nuclear family.

Out of 200 subjects 15 were educated till Bachelor degree, 38 have completed Intermediate, 57 were metric pass and 80 were educated till Primary. Source of awareness regarding organ donation, 86 persons from TV and Radio, 44 from news paper and magazines, 29 from family and friends, 21 from movies, 5 from internet and 2 from other sources (Table 1). The study shows the overall knowledge and attitude levels of individuals regarding organ donation.

The majority $61 \%$ individuals have inadequate knowledge, $23 \%$ have Moderate knowledge and $16 \%$ have adequate knowledge regarding organ donation. $84 \%$ individuals have negative attitude, $10 \%$ uncertain attitude and $06 \%$ positive attitude towards organ donation (Table 2). The mean score for knowledge was 5.21 with SD \pm 3.25 and the mean score for attitude was 23.96 with $\mathrm{SD} \pm 4.12$ which shows positive correlation between knowledge and attitude having correlation coefficient of $r=0.082$ regarding organ donation among individuals in the community (Table 3).
Table-1: Frequency and percentage distribution of demographic variables

\begin{tabular}{|c|c|c|c|c|}
\hline SN & \multicolumn{2}{|c|}{ Variables } & \multirow{2}{*}{\begin{tabular}{|l}
\multicolumn{1}{c}{$\begin{array}{c}\text { No. of } \\
\text { Participants }\end{array}$} \\
78
\end{tabular}} & \multirow{2}{*}{\begin{tabular}{|l}
$(\%)$ \\
39
\end{tabular}} \\
\hline 1 & \multirow[t]{6}{*}{ Age (years) } & $15-25$ & & \\
\hline & & $26-35$ & 52 & 26 \\
\hline & & $35-45$ & 33 & 16.5 \\
\hline & & $45-55$ & 17 & 8.5 \\
\hline & & $55-65$ & 13 & 6.5 \\
\hline & & $>65$ & 7 & 3.5 \\
\hline \multirow[t]{2}{*}{2} & \multirow[t]{2}{*}{ Gender Distribution } & Male & 128 & 64 \\
\hline & & Female & 72 & 36 \\
\hline \multirow[t]{4}{*}{3} & \multirow[t]{4}{*}{ Religion Distribution } & Hindu & 56 & 28 \\
\hline & & Christian & 2 & 1 \\
\hline & & Muslim & 13 & 6.5 \\
\hline & & Sikh & 129 & 64.5 \\
\hline \multirow[t]{2}{*}{4} & \multirow[t]{2}{*}{ Marital status } & Single & 67 & 33.5 \\
\hline & & Married & 133 & 66.5 \\
\hline \multirow[t]{2}{*}{5} & \multirow[t]{2}{*}{ Type of family } & Joint family & 104 & 52 \\
\hline & & Nuclear family & 96 & 48 \\
\hline \multirow[t]{4}{*}{6} & \multirow{4}{*}{$\begin{array}{l}\text { Educational } \\
\text { discipline }\end{array}$} & Bachelor degree & 15 & 7.5 \\
\hline & & Intermediate & 38 & 19 \\
\hline & & Metric & 57 & 28.5 \\
\hline & & Primary & 80 & 40 \\
\hline \multirow[t]{2}{*}{7} & \multirow[t]{2}{*}{ Family Income } & Above poverty line & 53 & 26.5 \\
\hline & & Below poverty line & 147 & 74.5 \\
\hline \multirow[t]{7}{*}{8} & \multirow{7}{*}{$\begin{array}{l}\text { Source of } \\
\text { awareness }\end{array}$} & T.V/Radio & 86 & 43 \\
\hline & & $\begin{array}{l}\text { News papers } \\
\text { /Magazines }\end{array}$ & 44 & 22 \\
\hline & & $\begin{array}{l}\text { Friends/ Family } \\
\text { members }\end{array}$ & 29 & 14.5 \\
\hline & & Physician/ Doctor & 15 & 7.5 \\
\hline & & A Movie & 21 & 10.5 \\
\hline & & Internet & 05 & 2.5 \\
\hline & & Other sources & 02 & 1 \\
\hline
\end{tabular}

Table-2: Distribution of overall Knowledge and attitude scores of individuals in percentage

\begin{tabular}{|l|l|l|l|}
\hline S. No & \multicolumn{2}{|c|}{ Parameter } & Percentage \\
\hline 1 & \multirow{3}{*}{ Knowledge scores } & Inadequate & 61 \\
\cline { 3 - 4 } & & Moderate & 23 \\
\cline { 3 - 4 } & & Adequate & 16 \\
\hline 2 & Attitude scores & Negative & 84 \\
\cline { 3 - 4 } & & Uncertain & 10 \\
\cline { 3 - 4 } & & Positive & 06 \\
\hline
\end{tabular}

Table-3: Co- relation between knowledge \& attitude regarding organ donation among individuals in community 


\begin{tabular}{|l|l|l|l|l|l|}
\hline Aspect & Maximum Scores & Range score & mean & SD & Correlation \\
\hline Knowledge & 10 & 8 & 5.21 & 3.25 & 0.082 \\
\hline Attitude & 40 & 32 & 23.96 & 4.12 & \\
\hline
\end{tabular}

\section{Discussion}

Our study suggests that the majority of population do not have positive attitudes toward organ donation more information and education are needed on this particular issue. About $6 \%$ of them would donate their organs without any hesitation, and a further $10 \%$ had some doubts and needed persuasion and $84 \%$ had negative attitude for organ donation. A similar study conducted by. Bilgel $H$ et al $[7,8]$ showed that $50.5 \%$ to $57.0 \%$ of the respondents would donate their own organs and $53.6 \%$ to $52.6 \%$ would donate their relatives' organs. A study in Saudi Arabia conducted by AlFaqih SR et al [9] found that the Islamic view supporting concepts of transplantation provided the strongest positive influence for organ donation. This view is also supported by our study; Positive correlation $(r=0.082)$ was seen between willingness to donate and knowledge of the allowance of organ donation.

A study conducted by Ali et al[10] $81.6 \%$ agreed that it was ethically correct to donate an organ. In general opinion, most commonly donated organs and tissues were kidney, cornea, blood and platelet. Ideal candidates for donating organ were parents ( $81 \%)$. Regarding list of options for preference to receive an organ, most of the individuals agreed on young age group patients and persons with family. Willingness to donate was significantly associated with knowledge of allowance of organ donation $(P=0.000)$. The present study also shows the Positive Correlation between knowledge and attitude regarding organ donation. Unfortunately, only $13.3 \%$ of the population was aware of the existence of the 'Transplantation of Human Tissues and Organ act[4], the knowledge of which could have far reaching impact on their decision to donate $[11,12]$. The study conducted in china by Chung et al [13] response rate was $94 \%(655 / 694)$.

A majority ( $85 \%$ ) had a 'positive' attitude, but only a small proportion (23\%) had signed the organ donation card this contradiction is due to the prevalence of local myths and misconceptions regarding organ donation in that area. Inconvenience and lack of knowledge about organ donor registration, and concerns about premature termination of medical treatment are responsible for such discrepancies.
Socio-cultural factors such as the traditional Chinese belief in preservation of an intact body after death, unease discussing death-related issues, and family objections to organ donation were significantly associated with a 'negative' attitude. Knowledge and action increased with medical education yet only a small proportion of medical students felt competent and confident in counselling patients on organ donation.

The Study Conducted by Kose et al [14] reveals $71.7 \%$ of individuals had positive views about transplantation of their own organs to a suitable recipient, with half of them giving being useful to others as a reason. Among individuals who had negative views about organ donation, the most important reason given was that it would mean a loss of bodily integrity. $44.1 \%$ of participants had positive views about transplantation of their relatives' organs to another person after death. $51.7 \%$ of participants had positive views about transplantation of the organs of a homeless person to another person after death.

\section{Limitations}

Main limitation of the study was that it includes only literate people.

\section{Conclusion}

The conclusion of the study is efficient methods for targeting general population are required. Better knowledge may ultimately translate into the act of donation. Efficient measures should be taken to educate the general population with relevant information with the involvement of media, health personnel, nongovernmental organizations like GYOF ( Gift your organ foundation) and MOHAN foundation and religious scholars.

\section{Reference}

01. Organ transplantation From Wikipedia, the free encyclopedia.

Available at [Article] [Crossref]

02. Womens Health gov. Organ donation and transplantation fact sheet.

Available at [Article] [Crossref]

03. Ethics of organ transplantation. Center for Bioethics. 2004;5-6. Available at

[Article] [Crossref] 
04. The transplantation of human organs act. $1994 ; 42$.

Available at [Article] [Crossref]

05. Organ donation.

Available at [Article] [Crossref]

06. Correlation.

Available at: [Article] [Crossref]

07. Bilgel H, Bilgel N, Okan N, Kilicturgay S, Ozen $Y$, Korun N. Public attitudes toward organ donation- A survey in a Turkish community. Transpl Int. 1991 Dec;4(4)243-5.

[Crossref]

08. Bilgel H, Sadikoglu G, Goktas O, Bilgel N. A survey of the public attitudes towards organ donation in a Turkish community and of the changes that have taken place in the last 12 years. Transpl Int. 2004 Mar;17(3)126-30.

[Crossref]

09. al-Faqih SR. The influence of Islamic views on public attitudes towards kidney transplant donation in a Saudi Arabian community. Public Health. 1991 Mar;105(2)161-5.

[Crossref]
10. Ali NF, Qureshi A, Jilani BN, Zehra N. Knowledge and ethical perception regarding organ donation among medical students. BMC Med Ethics. 2013 Sep 27;14;38.

doi: 10.1186/1472-6939-14-38 [Crossref]

11. Laederach-Hofmann K, Gerster BI. Knowledge, attitude and reservations of medical students about organ transplantation- results of a survey during the first year of study. Schweiz Med Wochenschr. 1998 Nov 21;128(47)1840-9.

[Crossref]

12. Bardell T, Hunter DJ, Kent WD, Jain MK. Do medical students have the knowledge needed to maximize organ donation rates?. Can J Surg. 2003 Dec;46(6)453-7.

[Crossref]

13. Chung CK, Ng CW, Li JY, Sum KC, Man AH, Chan SP, Cheung JY, Yu KP, Tang BY, Lee PP. Attitudes, knowledge, and actions with regard to organ donation among Hong Kong medical students. Hong Kong Med J. 2008 Aug;14(4)278-85.

[Crossref]

14. Kose OO, Onsuz FM, Topuzoglu. A Knowledge levels of and attitudes to organ donation and transplantation among university students. North Clin Istanbul. 2015;2(1)19-25.

[Crossref] 